\title{
THE USE OF CONTROL TOOLS ON PERFORMANCE AUDIT OF A GOVERNMENT'S SCIENTIFIC INSTITUTION: A CASE OF EMERGING ECONOMY
}

\author{
Parulian Silaen ${ }^{1}$, Shyam Bhati ${ }^{2}$, John Passant ${ }^{3}$, John McLaren ${ }^{4}$ \\ ${ }^{1,2}$ School of Accounting, Economics and Finance, University of Wollongong, \\ Australia \\ ${ }^{3}$ Australian National University, Australia \\ ${ }^{4}$ Charles Darwin University, Australia
}

\begin{abstract}
The paper investigates performance audit practiced by a government R\&D institution in a developing country. The study is undertaken in response to the question by many authorities on how to perform PA and what tools are used in practice (Barzelay, 1996; Leeuw, 1996; Roberts and Pollitt, 1994; Midwinter, 2008; Shand and Anand, 1995; Wynn-Williams, 2005). The study uses a case study to explore the utility of control tools in the performance audit of National Institute of Biological (NIB) by analysing the audit report of the Comptroller and Auditor General (CAG) of India. A set of control tools developed by Silaen and Williams (2009) for R\& D organisation are applied in this case. The elements of the control tools developed by Silaen and Williams (2009) consist of dimensions and values of representation. Four dimensions of control tools are given as directional, bureaucratic, scientific and financial. Three values of representation are given as external, internal and social value of representation. A matrix of dimensions and value of representation is developed, and applied to the audit report of NIB. It is concluded that CAG used all the four control dimensions across the three values of representation and arrived at a suitable recommendation to the Government of India. With a limitation to a single case, this study contributes to the literature by examining a unique case of a scientific organisation, NIB, and by understanding the way in which performance audit was used to enhance the accountability of public sector scientific institution. With a limitation to a single case study of NIB, this study has its originality to contribute to the literature by examining a unique case of a scientific organisation, National Institute of Biological in India, and by understanding the way in which performance audit was used to enhance the accountability of public sector scientific institution.
\end{abstract}

Keywords: Management Accounting, Management Control Systems, Performance Audit, Research and Development, Emerging Economy, Government Sector, India 


\section{INTRODUCTION}

The concept of new public management (NPM) is becoming popular across countries which lead to the need of public sector accountability through Performance Audit (PA). Many countries in the Organisations for Economic Cooperation and Development (OECD) countries have reformed their public management into New Public Management (NPM), which requires more accountability and need for performance audit (Leeuw, 1996; Politt, 2003).

The current literature on Performance Audit (PA) and its utility focuses on a number of aspects of performance audit such as need and scope of performance audit (PA), qualifications of auditors and audit criteria (Smith, Lanier, and Taylor, 1972; Kitindi, 1992), use of PA in the measurement of efficiency and effectiveness (Leeuw, 1996), development of audit expertise in government performance (Gendron, Y., D.J. Cooper, and B. Townley, 2007), trends and choices of PA (Pollitt, 2003). Since many of the implementation of PA uses a comparison process to measure the performance, many of authors question about "what kinds of tools are appropriate to be used for comparison by PA?" (Barzelay, 1996; Leeuw, 1996; Roberts and Pollitt, 1994; Midwinter, 2008; Shand and Anand, 1995; WynnWilliams, 2005).

This study investigate show a performance audit was implemented by Comptroller and Auditor General of India on NIB, and what kind of tools used by the auditors. A set of control tools developed by Silaen and Williams (2009) specifically for R\&D organisations are used to conduct this study. This study is expected to contribute to the literature on PA and helps in understanding the role of PA in increasing public accountability of a scientific organisation in an emerging country.

In the next section, the literature on PA is reviewed. This is followed by a discussion on the theoretical model of control tools for $\mathrm{R} \& \mathrm{D}$ organisations. Next, these control tools are then applied to the PA of the NIB in the section on analysis. Finally conclusions are arrived at based on the analysis of the case.

\section{LITERATURE REVIEW ON PERFORMANCE AUDIT}

Barzelay (1996, p.17) observed that the term performance auditing is complicated in definition. According to Barzelay (1996) the term 'performance auditing' is not widely employed either in government or in the academic literature. Language difficulties go beyond those of nomenclature. The term itself carries the implication that performance audit is a kind of auditing. Smith et al (1972) has been long identified this problem and indicated that performance audit (PA) have different names such as operational audit, functional audit, systems audit, management audit, and audit of management which directs attention to the policies and internal procedures which are normally developed, administered and enforced by management.

Since there is an increasing demand on public sector accountability, the role of PA becomes more important. The current literature on performance audit focuses on different aspects and uses of performance audit. Smith (1972, p. 272) undertook a study on performance audit and focused on three issues. The first issue related to the need for an audit of performance by CPA (Certified Practicing 
Accountants). The second was the scope of such an audit, and the third issue related to the audit standards required for such an audit. A group of professionals consisting of CPAs, Corporate Controllers, CFAs (Certified Financial Analysts), and Mutual Fund Managers were surveyed for this study. The survey indicated that CPAs as a strongly supported that performance audit could be done effectively by CPAs while others seemed to oppose this view on the ground of the nature of the management function and the qualification of CPAs to perform such audit. In regarding to the second issue, Smith et al (1972) investigated whether the scope of the PA should focus on management performance only or the means utilized by management or on both performance and means. The survey indicated that none of the respondents supported the idea of an audit of performance or means separately. Furthermore, the use of Generally Accepted Accounting Principles (GAAP) was not supported by the group other than CPAs. Therefore, these groups opined that CPAs were not properly qualified to perform such audit (Smith et al, 1972, p. 281). This study indicated a need for PA and for the auditor should not be limited to CPA qualification which focuses on financial audit only.

According to Leeuw (1996, p. 93) there are three important role of PA on NPM in government sector. Firstly, PA makes it possible to distinguish ambitions and intentions of management from realizations, secondly, auditing can unravel intended and unintended consequences of management actions and thirdly PA can unravel different aspects of the implementation and adoption of New Public management (NPM). In his study of Netherlands court, Leeuw (1996) investigated types of PA practice by the court. His study found that the Netherlands Court of Audit performs two type of PA namely substantive and systemic performance auditing. The substantive audit is assessing performance by using standards or benchmarks, while the systemic audit refers to assessing the adequacy of the performance information and its use which are comparative in nature (Leeuw, 1996, p. 95). Both types of performance audit (PA) depend on the comparison of actual result or processes with some standard.

Barzelay (1996) investigated different use of five variables by three audit functions and different goals between the three functions. The three audit functions are; traditional auditing, performance auditing, and program evaluation. The five variables investigated are image of government, meaning of effectiveness, primary goals of review, dominant mode of review, and role of reviewer. The study found that the five variables were found to be used in different ways among those three audit functions. In addition, the study also found that the three types of audit functions have different goals. The goals of traditional auditing are to ensure compliance accountability: The goals of PA are used to ensure performance accountability, while the goals of program evaluation are used in providing true and useful feedback on policy and program effectiveness (Barzelay, 1996, p.18).

Roberts and Pollitt (1994) investigated how National Audit Office (NAO) of Wales used the concept of Value For Money (VFM) for creating and safeguarding jobs in Wales in 1991 by focusing the study on the criteria used by PA (Roberts and Pollitt, 1994, p. 572). The VFM is measured by three criteria of economy, 
95 The Use Of Control Tools On Performance Audit

efficiency and effectiveness. Their study indicated a problem in using accounting measure of cost effectiveness. It is mentioned that,

...cost-effectiveness analysis cannot be used to compare the effectiveness of different programs which are intended to produce the same output, or to compare the effectiveness of a particular programme when applied to different location. The typical measure in cost effectiveness analysis is the net cost of producing one unit of the specified output (for example, per job created, life saved, child taught to read etc.) (Roberts and Pollitt, 1994, p.541)

Roberts and Pollitt (1994, p.546) finally concluded that, the NAO VFM (National Audit Office- Value For Money) focused on the area of financial aspect in which the issue of means in terms of management issues were not clearly covered.

Midwinter (2008) undertook a study on Best Value Audit in Scotland. The Best Value Audit attempted to use the performance assessment guidance that seemed to integrate planning, budgeting and performance management with regard to proper arrangement for securing economy, efficiency and effectiveness (Midwinter, 2008, p.441). Accordingly, it was mentioned that,

The links between planning, budgeting and performance are not

examined systematically in the Best Value Audits. Rather, the

benefits in terms of continuous improvement are assumed to flow

from sound planning. With few locally driven targets, the Commission's approach to auditing performance relies mainly on The

Accounts Commission Statutory Performance Indicator (SPIs), inspector's reports, and residential surveys(Midwinter, 2008, p.445).

The study of Midwinter (2008) indicated the use of comparison of performance index among councils as the criteria of PA which is similar to systemic audit of Leeuw (1996) in Netherlands.

Shand and Anand (1995) investigated the approaches and issues on PA in OECD member countries. Their study (Shand and Anand, 1995, p. 68) indicated problems in PAthat related to the criteria such as; auditor too judgmental, or too tough, and emphasise excessively on formal control models and on documentation. According to Shand \& Anand (1995, p. 69),

Developing standards or benchmarks again which performance is to

be judged becomes more contestable. It also becomes more debatable as to how relevant some criteria used by performance auditors are to performance issues.

Wynn-Williams (2005) investigated performance assessment of the Pharmaceutical Management Agency (Pharmac), a government unit under the New Zealand Ministry of Health. The performance indicator used are focused on cost saving overtime, price of medicine, and comparison performance over time (Wynn-Williams, 2005, pp.488-489). The performance assessment of Pharmac indicated the use of both substantive and systemic audit. However, the use of benchmarking as the audit criteria in Pharmac was also mentioned to be 
problematic (Wynn-Williams, 2005, p.489). Similar problem of audit criteria was also addressed by other authors (Pollitt, 2002, Roberts and Pollitt, 1994).

The literature review indicated that previous studies focus on different aspects of PA. They are about the need for the audit and qualifications of auditors (Smith et al 1972), benefits of PA in government sector (Leeuw, 1996), differences between traditional auditing, PA and program evaluation (Barzelay, 1996), evaluation of economy, efficiency and effectiveness in delivery of services by government (Robert and Pollitt, 1994), and how best value audit helps in integrating planning, budgeting and performance budgeting (Midwinter, 2008). However, there is no study investigated the tools used by the PA to measure the performance, and what values are used by the tools. This study focuses on the utility of control tools in performance audit in the specific setting of a public sector scientific institution.

\section{THORETICAL FRAMEWOTK ON CONTROL TOOLS}

Ouchi (1977, pp. 96-97) defined the management control systems by saying that,

...the control system itself consists primarily of a process for monitoring and evaluating performance, while the preconditions specify the reliability and validity with which such comparisons can be made.

Both domains of means and performance require criteria to which the means and performance are measured. The instrument to measure the means and performance in the domain of management control systems are called control tools (Silaen and Williams, 2009) which contain dimensions and values.The appropriateness of control tolls to be used in PA has been questioned by various authors (Leeuw, 1996; Barzelay, 1996; Robert \& Pollitt, 1994; Midwinter, 2008; Shand \& Anand, 1995; Wynn-Williams, 2005). The control tools to be used for measuring performance must be developed in relation to the characteristic of the entity being measured. Since the case investigated by this study is a scientific institution of a government sector in India, there is a need to develop control tools that contemplate the characteristic of the institution. Silaen and Williams (2009) proposed a set of control tools that is suitable for research and development (R\&D) organisations. It is argued that the objective of $R \& D$ function is to contribute new knowledge which cannot be measured monetarily in advance, deals with uncertain environment and therefore requires different model of management control systems (Silaen, 2009).

According to Silaen $(2009$, p. 60) "...control tools refers to instruments that are used in performing the control function." The core function of the control tools is to represent both the value of the desired end (output) and the means or effort. By having those values, the control function will be properly monitored, compared and evaluated on the effort as well as the achievement of the desired ends. The uses of control tools may be multiple, and may often be substituted to other uses. Therefore the appropriate control tools chosen may influence the success of the control systems (Silaen, 2009). According to Silaen (2009, p.52) 
there are two elements of control tools that need to be considered: dimensions and values of representation of the tools. These two elements is discussed in detail below.

\section{Dimensions of the control tools}

Silaen and Williams (2009) proposed two elements of the control tools as dimensions and values of representation. They consider the dimension as solid characteristics of the criteria that are used by the control systems. They classified four components of dimension of control tools as: Directional, Bureaucratic, Scientific and Financial dimensions. The Directional dimensions related to qualitative characteristics of the control tools which represent the general directions to be followed by the activity such as system goals, general policy guidelines, tasks and functions, mandate given, and strategic plan. The bureaucratic dimension of the control tools are characterised by either quantitative or qualitative characteristics which represent the technical tasks, such as standard operating procedures, quality control, inventory control, and scheduling including Program Evaluation and Review Technique (PERT), Critical Path Method (CPM), and production scheduling. As the control tools are to be used for R\&D organisation, the control tools need to contain the scientific dimensions which are used particularly to measure ideas and innovations such as new or improved processes, products or techniques, patents and patent applications, scientific publications, membership of professional organisations and so forth. This dimension may contain either quantitative or qualitative characteristics. Finally, the financial dimension of the control tools is the monetary measurement which is commonly used by accounting control such as budgets, cost effectiveness, standard costs and return on investment.

\section{Values representation in the control tools}

The control tools are instrument of the control function to assess the actual performance with regard to the expected achievement or desired ends. Therefore, the control tools should play a role as an agent that contains values that ideally represents these two extreme points. Silaen and Williams (2009) proposed three values of representation available in the control tools: external values, internal values, and social values. The External values is the value of external party which is considered to be more independent and objective. The market mechanism to define a fair price on the market control (Ouchi, 1979; Lebas\&Weigenstein, 1986) such as bid price. Scientific values defined by scientific community can be considered as external values.

The Internal values refer to values that are developed by an internal party with reference to the internal conditions of the organisation (Silaen and Williams, 2009). Some authors have given examples of the internal values such as the bureaucratic control (Ouchi, 1979, Lebas\&Weigenstein, 1986) that is commonly labelled by setting rules, standard operating procedures and policies, standard costs. The process to setting the internal values may be done by force by dominating party within the organisation such as management team of the organisation while ordinary employees may need to meet this value. Therefore, 
setting of internal value would have a greater chance for dysfunctional behaviour if it is used in highly uncertain and low goal congruence situation.

The last value is Social value which refers to value that result from social interaction among the members of an organisation. The social value may be reflected in the organisational culture. The value setting process of the social values is not done by force as in internal values rather; it is accepted by the members willingly. The social values are not affected by clear or unclear boundaries of desired ends, because it is set by the social interactions that have a chance to change and adjust overtime. The use of social values in the control system will have less chance to drive dysfunctional behaviour than the internal values. Although these three values may be seen in separation, in exercising the control tools there would be a combination among these values embodied in the set of control tools applied.

\section{Operation of the control tools' elements}

Having defined the dimensions and the value of representation of the control tools, there is a need to illustrate the operation of these two elements of control tools. The directional dimension of control tools may be set by internal members of the organisation, but the value that is given to this dimension may be a combination of the three values: internal, external and social values. For example, in setting the system goals or general policies guidelines, the members of the organisation would be influenced by internal values regarding the conditions of the organisation. However, the expected conditions would also be influenced by the external environment which contains the external value. Furthermore, the members of the organisation would also be influenced by their individual belief which represents the social values.

In turn, the bureaucratic dimension measured by standard operating procedures and scheduling may deal with internal affairs and may be dominated by internal values and social values. The standard operating procedures and scheduling are constructed by the members of the organisation, and these would be based on their past experience and belief. The scientific dimension used by R\&D organisation may be constructed by a combination of the three values. However, the emphasis of either one of the three values will depend on different stage of R\&D operation. In the basic and applied research operations for example, to measure the intangible output such as ideas, thought and concepts, the scientific dimension may be dominated by external and social values to measure the contribution of the research output to knowledge. These may be seen in various aspects such as; patents or patents applications, scientific publications, memorandums, manuscripts, oral presentations, and independent panel and expert rating. The scientific dimension of the control tools that contain social values may include the originality of written work, professional society membership, and creativity ratings. Furthermore, in the product development operation in which the description of expected output is clearer than basic and applied research, the scientific dimension of control tools may be dominated by internal values such as peer or supervisory rating, current organisational status, and also external values such as customers demand on quality of the products. 
The financial dimension of control tools may be described by internal and/or external values. Though the control tools in this category mostly contain internal values, some of them may also consist of external values such as benchmarking rate of return, transfer pricing, and budget set up by controlling institution. The success of the control systems may occur when each control element matches the plausible requirement of others.

\section{THE CASE OF NATIONAL INSTITUTE OF BIOLOGICAL OF INDIA}

The case used in this study is on the report of Comptroller and Auditor General of India for the year ended March 2008 of a government institute called the National Institute of Biological (NIB). The institute was established in January 1992. The expected role of NIB was to act as the national control laboratory to ensure the availability of biological products in good quality for domestic consumption as well as for export. The NIB is under the administrative control of the Ministry of Health and Family Welfare Secretary of India. The institute is headed by a Director and assisted by five deputy directors with the following departments: Quality control and development; Training and technical support; Animal production and quarantine; Environment and personnel safety; and Administration and finance. The cost of establishing the institute had been revised two times and finally come to total of Rs. 2,560 million.

Since the audit is related to performance, therefore, the mandate given to the unit being audited would become key aspects for PA. The mandate of the NIB are presented in table 1 below.

\section{Table 1: Mandate given to NIB by Government of India}

1. To undertake systematic examination of the quality of biologicals ${ }^{1}$ and immunobiological ${ }^{2}$ products, with a view to enable the release of indigenous and imported products after certification according to procedures prescribed under the Drugs and Cosmetics Act.

2. To establish National Reference Standards and serve as a repository for reference standards and reagents for biological and immunobiologicals.

3. To develop suitable networks/linkages with related institutions set up by the Central or State Governments or within Universities so as to effectively disseminate knowledge, develop manpower and act as a resource backup for long-term development of reference standards and quality control of biologicals/immunobiological products

4. To develop and establish pharmacopoeia specifications appropriate for biological and immunobiologicals for use in India, in consultation with the Indian Pharmacopoeia Committee

5. To function as an accredited testing and reference laboratory for quality control of biological products available in the future and evaluate and advise on emerging technologies in these fields in terms of their specificity, sensitivity and replicability 


\begin{tabular}{l} 
6. To provide training to scientific and technical personnel in the procedures for \\
1 development of standardization and quality control methods of biological \\
\hline $\begin{array}{l}\text { 7. To develop technical guidelines/manuals on standards to be used by } \\
\text { manufacturers and also for training scientific and technical manpower for } \\
\text { standardization and quality control. }\end{array}$ \\
\hline $\begin{array}{l}\text { 8. To monitor ongoing research, establish linkages and exchange personnel with } \\
\text { different institutions in India and abroad for the furtherance of its mandate }\end{array}$ \\
\hline
\end{tabular}
Source: Comptroller and Auditor General of India (2008), page 3

\section{PERFORMANCE AUDIT}

The audit on performance of the NIB was undertaken by Comptroller and Auditor General of India and presented in the report no. PA30 of 2008-2009. The audit report covered the records of the NIB pertaining to the period 2003/2004 to 2007/2008. The objective of the audit of NIB was to verify five important aspects that are related to the mandate of NIB as in table 2.

\section{Table 2: Objectives of the Performance Audit}

1. The institute fulfilled its role of systematic examination of the quality of indigenous and imported biological and immunobiological products and certified their quality; developed reference standards, quality control and testing procedures for them and finalized pharmacopoeia specifications appropriate for biological and immunobiological products;

2. It contributed to the development of human resources in the field of biological and immunobiological products through networking and linkages with national and international institutes for knowledge sharing and dissemination and conducted effective training programmes for scientific and technical personnel to address the assessed needs for training with optimum utilisation of its capacity;

3. the processes, procedures and resources deployed by the institute were commensurate with its mandate and were efficiently managed for timely achievement of the intended objectives;

4. the procurement process followed by the institute was transparent and ensured economy in purchases and the purchase of equipment and construction of the Laboratory and Animal House and other buildings were as per the specifications and requirements of the institute;

5. the internal controls within the institute and oversight by the Ministry were effective and addressed the shortcomings and deficiencies in time and the

\footnotetext{
${ }^{1}$ Biologicals are vaccines, cultures and other preparations made from living organisms and their products, intended for use in diagnosing, immunizing, or treating.

${ }^{2}$ Immunobiologicas are antigenic or antibody containing preparation derived from animals or human donors and used for immunization and immune therapy
} 
101 The Use Of Control Tools On Performance Audit

controls provided assurance against frauds, misuse and waste to ensure economic and efficient use of the inputs for the intended objectives

Source: Comptroller and Auditor General of India, 2008, .p 5

The performance audit on NIB is to verify the five aspects above by using five audit scope and criteria as presented in table 3 below.

\section{Table 3: Audit Scope and Criteria}

1. the provisions of the Drugs and Cosmetics Act, 1940 and the rules framed there under,

2. the mandate of NIB as enshrined in the Memorandum of Association (MOA) and the Expenditure Finance Committee (EFC) Memos (1991,2000),

3. adherence to good laboratory practices (GLP),

4. adherence to drug specifications in the pharmacopoeia, and

5. the provisions of the Standard Operating Procedure Manual (SOP) of NIB

Source: Comptroller and Auditor General of India 2008, p.5

Using the five aspects as the audit scope and criteria, the PA verified the achievement of NIB in regard with the mandate given, examined the records, and verify physical utilisation of equipment within the period from 2003/2004 to $2007 / 2008$ financial year. The PA of NIB indicated dissatisfaction with the performance of NIB and summarised the findings into four broad categories (Comptroller and Auditor General of India, 2008, p.7):

1. Non-achievement of the primary objectives for which NIB was set up

2. Lapses in scientific activities

3. Lapses in purchases of equipment and their non/underutilization

4. Lapses in administrative and internal control

The audit finding above lead the performance auditors to prepare the recommendation to the management of NIB and the Ministry of Health and Family Welfare Secretary of India as presented in table 4 below.

\section{Table 4: Audit Recommendation}

1. NIB should conduct all the crucial tests in accordance with the concerned pharmacopoeia so that the quality of biological is ensured before release in the market.

2. Concerted efforts should be made for development of human resources in the field of biological and immunobiological products through proper training of scientific and technical personnel. Besides, efforts should be made for dissemination of knowledge through networking and linkages with national and international institutes.

3. The Ministry and NIB should ensure deployment of sufficient scientific and technical manpower commensurate with the available infrastructure in NIB in a time-bound manner. 
4. NIB should systematize its procurement procedures and make proper assessment of the actual requirements of equipment before procurement. Besides, concerted efforts should be made to ensure proper utilization of the procured equipment.

5. The internal controls within the institute and oversight by the Ministry should be strengthened.

6. The Ministry should fix responsibility for the various lapses observed during audit, such as batch release certification by NIB without conducting the full complement of tests prescribed by the pharmacopoeia; sending of samples by subordinate offices of DCG (I) to NIB for quality control testing despite instructions of the Ministry to the contrary and purchase of a DNA sequencer, an expensive equipment, without any requirement by the institute

Source: Comptroller and Auditor General of India, 2008, pp.9-26

The next section presents a discussion on the possible used of dimensions and value of representation in the audit criteria of the case.

\section{ANALYSIS}

The performance and accountability of National Institute of Biologicals (NIB) is analysed using the set of control tools developed by Silaen and Williams (2009). The analysis uses the audit report of the Comptroller and Auditor General (CAG) of India for the year ended March 2008 along with the information given in the Annual Report of Ministry of Health and Family Welfare, Government of India. The objectives of the PA of NIB were to verify whether or not the mandate was undertaken efficiently and effectively. The audit objectives of the NIB were then measured by the five scopes and criteria as presented in table 3 .

Since the audit objectives are measured by the criteria and scopes, therefore it is possible to investigate which dimensions and values are likely used by each objectives of the performance audit of NIB as presented in table 5 below.

Table 5: Dimensions and values of the audit objectives of NIB

\begin{tabular}{|c|c|c|}
\hline The objectives are to verify the following: & Dimension & Values \\
\hline 1.1. The institute fulfilled its role of systematic & Bureaucratic & Internal \\
\hline $\begin{array}{l}\text { examination of the quality of indigenous and } \\
\text { imported biological and immunobiological }\end{array}$ & Scientific & External \\
\hline products and certified their quality; & Directional & Internal \\
\hline 1.2. Developed reference standards, quality & Bureaucratic & Internal \\
\hline control and testing procedures for them and & Scientific & External \\
\hline finalized pharmacopoeia specifications & & Social \\
\hline $\begin{array}{l}\text { appropriate for biological and } \\
\text { immunobiological products; }\end{array}$ & & \\
\hline $\begin{array}{l}\text { 2.1. it contributed to the development of human } \\
\text { resources in the field of biological and } \\
\text { immunobiological products through } \\
\text { networking and linkages with national and } \\
\text { international institutes for knowledge sharing }\end{array}$ & $\begin{array}{l}\text { Directional } \\
\text { Scientific }\end{array}$ & $\begin{array}{l}\text { Internal } \\
\text { External }\end{array}$ \\
\hline
\end{tabular}




\begin{tabular}{|c|c|c|c|}
\hline 2.2 & $\begin{array}{l}\text { and dissemination } \\
\text { Conducted effective training programmes for } \\
\text { scientific and technical personnel to address } \\
\text { the assessed needs for training with optimum } \\
\text { utilisation of its capacity; }\end{array}$ & $\begin{array}{l}\text { Directional } \\
\text { Bureaucratic }\end{array}$ & $\begin{array}{l}\text { Internal } \\
\text { Internal }\end{array}$ \\
\hline 3.1 & $\begin{array}{l}\text { the processes, procedures and resources } \\
\text { deployed by the institute were commensurate } \\
\text { with its mandate } \\
\text { and were efficiently managed for timely } \\
\text { achievement of the intended objectives }\end{array}$ & $\begin{array}{l}\text { Bureaucratic } \\
\text { Directional } \\
\text { Bureaucratic }\end{array}$ & $\begin{array}{l}\text { Internal } \\
\text { Internal } \\
\text { Internal }\end{array}$ \\
\hline 4.1. & $\begin{array}{l}\text { The procurement process followed by the } \\
\text { institute was transparent and ensured } \\
\text { economy in purchases and the purchase of } \\
\text { equipment and construction of the Laboratory } \\
\text { and Animal House and other buildings were } \\
\text { as per the specifications and requirements of } \\
\text { the institute; }\end{array}$ & $\begin{array}{l}\text { Bureaucratic } \\
\text { Directional } \\
\text { Financial }\end{array}$ & $\begin{array}{l}\text { Internal } \\
\text { Internal } \\
\text { Internal }\end{array}$ \\
\hline 5.1. & $\begin{array}{l}\text { the internal controls within the institute and } \\
\text { oversight by the Ministry were effective and } \\
\text { addressed the shortcomings and deficiencies } \\
\text { in time } \\
\text { and the controls provided assurance against } \\
\text { frauds, misuse and waste to ensure economic } \\
\text { and efficient use of the inputs for the intended } \\
\text { objectives }\end{array}$ & & \\
\hline 5.3 & $\begin{array}{l}\text { the internal controls within the institute and } \\
\text { oversight by the Ministry were effective and } \\
\text { addressed the shortcomings and deficiencies } \\
\text { in time } \\
\text { and the controls provided assurance against } \\
\text { frauds, misuse and waste to ensure economic } \\
\text { and efficient use of the inputs for the intended } \\
\text { objectives }\end{array}$ & $\begin{array}{l}\text { Bureaucratic } \\
\text { Directional } \\
\text { Financial } \\
\text { Directional }\end{array}$ & $\begin{array}{l}\text { Internal } \\
\text { Internal } \\
\text { Internal } \\
\text { Internal }\end{array}$ \\
\hline
\end{tabular}

Source: Comptroller and Auditor General of India (2008), page 5

The dimensions and values used by the audit objectives (table 5) are also reflected by the findings of the audit which are summarised into six subjects and presented in table 6 below.

Table 6: The Findings of the Performance Audit of NIB

\begin{tabular}{|c|c|c|c|}
\hline & Audit Findings & Dimension & Values \\
\hline 1 & $\begin{array}{l}\text { Even after } 16 \text { years of its inception and } \\
\text { expenditure of Rs. } 256 \text { crore, which was } 95 \text { per }\end{array}$ & $\begin{array}{l}\text { Financial } \\
\text { Directional }\end{array}$ & $\begin{array}{l}\text { Internal } \\
\text { Internal }\end{array}$ \\
\hline
\end{tabular}




\begin{tabular}{|c|c|c|c|}
\hline & $\begin{array}{l}\text { cent of the total project cost, the National } \\
\text { Institute of Biological (NIB) could not fulfil its } \\
\text { role of ensuring availability of safe and good } \\
\text { quality biological products for consumption in } \\
\text { India. NIB could not achieve its intended } \\
\text { objectives of systematic examination of the } \\
\text { quality of biological, development of national } \\
\text { reference standards and human resource } \\
\text { development in the field of biological. As a } \\
\text { result, in spite of the establishment of a vast } \\
\text { infrastructure, several batches of biological } \\
\text { products continued to be released without } \\
\text { independent quality assurance testing. In the case } \\
\text { of imports, the country was compelled to rely } \\
\text { essentially on claims of safety, potency and } \\
\text { efficacy made by foreign manufacturers/drug } \\
\text { regulatory authorities of other countries. }\end{array}$ & $\begin{array}{l}\text { Bureaucratic } \\
\text { Scientific }\end{array}$ & $\begin{array}{l}\text { Internal } \\
\text { External } \\
\text { and } \\
\text { Social }\end{array}$ \\
\hline 2 & $\begin{array}{l}\text { NIB did not deploy Good Laboratory Practices } \\
\text { compliant processes and procedures. Serious } \\
\text { scientific lapses and malpractices were observed } \\
\text { during audit. NIB was certifying blood products } \\
\text { stating compliance with requirements of the } \\
\text { pharmacopoeia without carrying out critical tests } \\
\text { required under the pharmacopoeia. For example, } \\
\text { it had certified many batches of immunoglobulin, } \\
\text { a lifesaving drug, without carrying out tests to } \\
\text { ascertain whether the biological was actually } \\
\text { immunoglobulin; Whether it was safe for use and } \\
\text { would not lead to abnormal toxicity and fever } \\
\text { when administered and whether it would remain } \\
\text { stable under given temperature conditions. }\end{array}$ & $\begin{array}{l}\text { Bureaucratic } \\
\text { Scientific }\end{array}$ & $\begin{array}{l}\text { Internal } \\
\text { External } \\
\text { and } \\
\text { Social }\end{array}$ \\
\hline 3 & $\begin{array}{l}\text { Owing to complaints regarding large scale } \\
\text { irregularities in testing and reporting of results, } \\
\text { the Ministry stopped the testing of biological by } \\
\text { NIB in July, } 2007 \text { and forbade all subordinate } \\
\text { offices of the Drug Controller General of India } \\
\text { (DCGI) to send samples to NIB for testing. } \\
\text { Despite this, some subordinate DCGI offices } \\
\text { continued to send samples to NIB for batch } \\
\text { release certification, rendering such are testing } \\
\text { irregular. Most of the samples received by NIB } \\
\text { after July, 2007 were sent by one particular } \\
\text { subordinate office of DCGI and belonged to one } \\
\text { particular manufacturer/company. }\end{array}$ & $\begin{array}{l}\text { Bureaucratic } \\
\text { Scientific }\end{array}$ & $\begin{array}{l}\text { Internal } \\
\text { External } \\
\text { and } \\
\text { Social }\end{array}$ \\
\hline 4 & One of the main reasons for underperformance of & Bureaucratic & Internal \\
\hline
\end{tabular}




\begin{tabular}{|c|c|c|c|}
\hline & $\begin{array}{l}\text { NIB, in addition to the abovementioned lapses, } \\
\text { was non-deployment of commensurate human } \\
\text { and physical resources for timely achievement of } \\
\text { intended objectives. This, coupled with undue } \\
\text { delays in decision making and lack of } \\
\text { coordination and proper planning, led to delays } \\
\text { in construction of infrastructure and inefficient } \\
\text { management and utilization of available } \\
\text { resources. Despite the completion of the main } \\
\text { Laboratory Building and Animal House in } \\
\text { February, 2006, only } 75 \text { persons were deployed } \\
\text { in NIB as of October, } 2008 \text {, against the assessed } \\
\text { requirement of } 363 \text {. }\end{array}$ & $\begin{array}{l}\text { Directional } \\
\text { Financial }\end{array}$ & $\begin{array}{l}\text { Internal } \\
\text { Internal }\end{array}$ \\
\hline 5 & $\begin{array}{l}\text { The procurement process followed by the } \\
\text { institute did not ensure sufficient competition and } \\
\text { was marred with irregularities. Equipment was } \\
\text { procured without proper assessment of actual } \\
\text { requirements and cares to stagger purchases in } \\
\text { tune with anticipated usage, leading to poor or no } \\
\text { utilization of costly equipment. This resulted in } \\
\text { wasteful deployment of funds in procurement } \\
\text { and unfruitful expenditure on idle maintenance } \\
\text { for long spells of time. About } 88.5 \text { per cent of the } \\
\text { total fixed equipment installed in NIB was lying } \\
\text { unutilized. The warranty periods of most of the } \\
\text { fixed equipment had lapsed even before they } \\
\text { were put to use. }\end{array}$ & $\begin{array}{l}\text { Bureaucratic } \\
\text { Financial }\end{array}$ & $\begin{array}{l}\text { Internal } \\
\text { Internal }\end{array}$ \\
\hline 6 & $\begin{array}{l}\text { Only one meeting of the General Body and three } \\
\text { meetings of the Governing Body were held } \\
\text { against } 15 \text { such meetings mandated under the } \\
\text { Rules and Regulations of NIB during the five- } \\
\text { year period reviewed by Audit. Deficient control } \\
\text { and oversight over the performance of NIB } \\
\text { deprived the Ministry of opportunities to address } \\
\text { NIB's shortcomings and deficiencies in time }\end{array}$ & Bureaucratic & Internal \\
\hline
\end{tabular}

Source: Comptroller and Auditor General of India (2008), pp. 1-2

\section{Scientific Dimension}

Scientific dimension is aspecific dimension in control tools fora $R \& D$ organisation (Silaen and Williams, 2009). The scientific dimension assessed on the accountability of NIB can be observed from the audit objective (Table 5) and the audit findings (Table 6). The scientific dimension of the control tools are needed to confirm the first and the second audit objectives set for NIB (Table 5).

As indicated by the audit findings (table 6), the scientific dimensions were used by the control tools and lead CAG to come to the first three audit findings (see Table 6). Finding 1 indicated that "NIB could not achieve its mandate of 
systematic examination of the quality of biological, development of reference standards and human resource development in the field of biological". Finding two indicated that "...there were considerable lapses in the fulfilment of scientific objectives". The CAG observed that NIB was certifying blood products stating compliances with requirements of pharmacopoeia and certified many batches of immunoglobulin without carrying out tests to ascertain whether the biological was in fact immunoglobulin. The testing irregularities as mentioned in finding 3 also indicated the measure of scientific dimension. The audit report of CAG is very critical of the lack of fulfilment of scientific dimension of mandate given to NIB. The scientific dimension of the control tool used by CAG was particularly useful in measuring the performance of NIB on their processes, products, techniques and activities. CAG have relied on the scientific dimension with the social and external values of representation in arriving at their recommendation on the scientific mandate given to NIB by Government of India.

\section{Directional Dimension}

According to Silaen and Williams (2009), the directional dimension of control tools is related to the general directional set out to be followed by the organisation such as organisational goals, general policy guidelines, strategic plan, mandate, and task and function. The directions of NIB are set in the form of mandate given to them (table 1) and to be verified by CAG as indicated in the audit objective of NIB (see table5). To examine the directional dimension of performance of NIB, CAG investigated to find if the processes, procedures and resources deployed by NIB were appropriately carried out toward and within the directions given to NIB. In doing this the Comptroller and Auditor General (CAG) relied on external and social values of representations of the tools. CAG report found in first finding indicated that "NIB could not fulfil its role of ensuring availability of safe and good quality of biological products...". In addition, CAG also found (finding four) that "undue delay in decision making (which is an internal value) at NIB, lack of coordination and proper planning led to the nonfulfilment of the mandate set for direction of NIB. The NIB could not achieve its intended mandate of human resource development and linkages with central or state government institutions and universities (see audit objectives 2.1, in table 5). The non-achievement of NIB in its directional dimension led to CAG recommendation that "concerted effort should be made for the development of human resources in the field of biological and immunological products through proper training of scientific and technical personnel. The directional dimension of control tool use by CAG was based on the measurement of internal values of decision making or the lack of it at NIB but resulted in potential consequences for external and social value as due to lack of decision making at NIB appropriate linkages with external stakeholders could not be developed.

\section{Bureaucratic Dimension}

The bureaucratic dimension measured by CAG can be observed in mostly all audit objectives set for NIB (see table 5). The existence of standard operating procedures can be seen clearly in objectives 3 to 5 . The third audit objective pointed out $\mathrm{CAG}$ to investigate if the processes, procedures and resources 


\section{The Use Of Control Tools On Performance Audit}

deployed by NIB were commensurate with their mandate and was efficiently managed for timely achievement of their intended objectives. The CAG also set the objective four to investigate if the procurement procedures followed by the institute was transparent and ensured the economy in purchases of equipment and construction of facilities. Further, in objective five,the CAG also investigated the internal controls of NIB to find out if the oversight of the Ministry of Health and family Welfare, Government of India was effective and addressed any shortcomings in working of NIB.

The audit finding indicated that the Comptroller and Auditor General (CAG) observed that NIB did not deploy Good Laboratory Practice compliant processes and procedures. Serious scientific lapses and malpractices were observed in the working of NIB by CAG during audit. Owing to these complaints, the Ministry at one stage stopped testing of biological by NIB in 2007 and forbade offices of Drug Controller General of India (DGCI) to send drug samples to NIB for testing. Despite a clear direction by the Ministry not to send samples to NIB, one office of DGCI did send samples to NIB for testing. The use of bureaucratic dimension with its internal values is evident here. Although this lack of compliance on rules and regulations is internal to NIB, there are potential external consequences as outside parties are involved with NIB. Further CAG report mentions that undue delay in decision making at NIB led to delays in construction of infrastructure and inefficient management and utilisation of available resources. The procurement process followed by NIB did not ensure sufficient competition and was marred by irregularities. The use of bureaucratic dimension is further evidenced by the fact that only one meeting of general body and three meetings of the governing body of NIB were held against fifteen such meetings mandated under the rules and regulations of NIB. Lack of compliance on rules and regulations and oversight over the performance of NIB deprived the Ministry of opportunity to address NIB's shortcomings and deficiencies. CAG's examination of bureaucratic dimension of control tool of NIB had mostly internal value of representation as internal procedures, processes and guidelines were examined to understand the shortcomings and lack of control in the working of NIB.

\section{Financial Dimension}

Financial dimension is the last dimensionin the use of control tools. Financial dimension of control tools provides the monetary measurements of an organisation's performance. Financial dimension uses accounting tools such as budgets, cost effectiveness, standard costs and return on investments as mechanisms of evaluation. In the performance audit of NIB, CAG focused on the controls provided against frauds, misuse and waste to ensure economic and efficient use of inputs for intended objectives by NIB. NIB was established by Government of India at a cost of Rs2560 million. According to CAG report (table 6), in spite of this expenditure, National Institute of Biological could not fulfil its role of ensuring availability of safe and good quality biological products for consumption in India. The laboratory buildings of NIB were completed in 2006, but only 75 persons were employed by NIB against the assessed requirement of 363. About $88.5 \%$ of total fixed equipment installed in NIB was underutilised. The 
warranty period of most of the fixed equipment lapsed even before the equipment was put to use. CAG in their report recommended that NIB should systematize its procurement procedures and make proper assessment of actual equipment before procurement. Effort should be made to ensure utilisation of the procured equipment. The financial dimension of control tools examined by CAG led to the conclusion that NIB needed to address the lapses in the procurement and their under-utilisation/non-utilisation. The financial dimension in this case is based on the internal value of representation as all the aspects are related to the internal working of NIB.

From discussion given in previous section it is clear that $\mathrm{CAG}$ has effectively used four dimensions of control tools- scientific, directional, bureaucratic and financial - to assess the performance of National Institute of Biological (NIB). Through its performance audit report, CAG has examined various aspects of performance of NIB keeping in view its mandate and made recommendations which would help NIB to improve its accountability. In the discussion above, each of the four dimensions were used independent of each other in explaining the use of control tools for the performance audit of NIB. Many times these dimensions are linked to each other. For example, the first finding of $\mathrm{CAG}$ consists of financial dimension that measures the expenditure dispensed by NIB and was linked to directional and bureaucratic dimensions indicated by the mandated functions of NIB and to scientific dimension in controlling the quality of biological. Table 6 summarises the findings of CAG on the performance of NIB. Each of the findings mentioned in table 6 include more than one dimension except finding no 6 . For example, finding 1 includes all the four dimensions - scientific, directional, bureaucratic and financial. Similarly each of the findings is based on internal, external or social values of representation. Since the performance of NIB has implications for internal values of NIB, on organisations external to NIB and on the public accountability of scientific services to larger community, the CAG report appropriately bases its recommendations on all the four dimensions and three values of representations.

\section{CONCLUSION}

This attempted to answer the questions of "what kinds of tools are appropriate to be used for comparison by PA?" The study investigated how the PA was implemented in NIB, a public sector Research and Development organisation in India. In regarding to the tools used by the auditors to undertake the PA, the study uses the two elements of control tools developed by Silaen (2009). The control tools contain two elements; dimensions and values of representation. The dimension of the control tools consists of four components; directional, bureaucratic, scientific and financial dimension. The values of representation of the control tools contains three values; internal, external and social value. The study investigated the use of the dimensions and the values of representation on the case of performance audit of NIB through the mandate of NIB, the audit objectives, and the audit finding of CAG report.

From discussion given in previous section it is clear that CAG has effectively used four dimensions of control tools- scientific, directional, 
bureaucratic and financial - to assess the performance of National Institute of Biologicals (NIB). Through its performance audit report, CAG has examined various aspects of performance of NIB keeping in view its mandate and made recommendations which would help NIB to improve its accountability. In the discussion above, each of the four dimensions were used independent of each other in explaining the use of control tools for the performance audit of NIB. Many times these dimensions are linked to each other. For example, the first finding of CAG consists of financial dimension that measures the expenditure dispensed by NIB and was linked to directional and bureaucratic dimensions indicated by the mandated functions of NIB and to scientific dimension in controlling the quality of biological. Table 6 summarises the findings of CAG on the performance of NIB. Each of the findings mentioned in table 6 include more than one dimension except finding no 6. For example, finding 1 includes all the four dimensions - scientific, directional, bureaucratic and financial. Similarly each of the findings is based on internal, external or social values of representation. Since the performance of NIB has implications for internal values of NIB, on organisations external to NIB and on the public accountability of scientific services to larger community, the CAG report appropriately bases its recommendations on all the four dimensions and three values of representations.

The study finds that the dimensions and values of representations can be identified in the mandate of NIB and the audit objectives. Therefore, in order to evaluate the performance of NIB, CAG has used all the four dimensions and three values of representation in the audit objectives as given in table 5. In line with the mandate and the audit objectives, the findings of CAG are also based on four dimensions and three values of representations as given in table6. This progression of use of dimensions during the audit process suggests that for proper performance audit interplay of dimensions and values of representations leads to better understanding of performance audit.

The study contributes to the literature by highlighting theuse of control dimension and values of representation and applying these concepts to a case study on the performance of a scientific organisation in public sector. The use of the dimensions and the values of representation seem to be able to capture the dimension of the NIB as well as the value of representation of a government and R\&D unit.

What the case tells us in terms of contribution to literature can be suggested as follows:

1. Performance audit can enhance public accountability of scientific institutions as in the case of NIB India.

2. The accountability of scientific institutions should not be limited to scientific dimensions alone but should include financial, directional and bureaucratic dimensions.

3. Each of the four dimensions is not independent of other but interplay of all the four dimensions occur in performance and audit. 
4. In implementing these tools there is a need to put the weight of each tools in measuring the performance. The weight may be based on the degree of importance of each item which are measured by the tool in relation to the role of the unit to the society.

The study is however, limited to a single case study of NIB, a government unit of India using audit report as a source of data. Further study in a different cultural and contextual setting is needed to enrich the collection of case studies on the criteria used by performance audit in public sector and to understand the varied use of control tools in performance audit. 


\section{REFERENCES}

Barzelay, Michael (1996), "Performance Auditing and the New Public Management: Changing Roles and Strategies of Central Audit Institutions", in Performance Auditing and the Modernisation of Government, PUMA, pp. $15-56$.

Comptroller and Auditor General of India (2008), Performance Audit of National Institute of Biologicals, Report number PA30 of 2008-09.

Gay, Grant and Roger, Simnett (2003), "Auditing and Assurance Services in Australia, 3nd edition, McGraw Hill, Australia.

Gendron, Yves, David J. Cooper, and Barbara Townley (2007), "The Construction of Auditing Expertise in Measuring Government Performance", Accounting Organisations and Society, No. 32, pp. 101-129.

Kitindi, Ernest G. (1992), International Journal of Government Auditing; Apr; 19, 2; pp. 8-11.

Lebas, Michel, and J. Weigenstein (1986): "Management Control: The Roles of Rules, Markets and Culture, Journal of Management Studies, 23, 3, May, pp. 259-272.

Leeuw, Frans L. (1996), "Performance auditing, new public management and performance improvement: questions and answers", Accounting, Auditing, and Accountability Journal, vol. 9, No. 2, pp. 92-102.

Midwinter, Arthur (2008), "Performance Management and Best Value Audit in Scotland: A Research Note on Theory and Practice', Financial Accountability and Management, Vol. 24, No. 4, pp. 439-453.

Ministry of Health and Family Welfare, Government of India, Annual Report, 2008-09.

Ouchi, W. G (1977): "The Relationship Between Organizational Structure and Organizational Control", Administrative Science Quarterly, pp. 95-113.

Ouchi, W. G (1979): "A Conceptual Framework for the Design of Organizational Control Mechanisms", Management Science, pp. 833-848.

Pollitt, Christopher, (2003), "Critical Perspectives on Accounting, 14, pp. 157170.

Roberts, Simon and Christopher Pollitt (1994): "Audit or Evaluation? A National Audit Office VFM Study”, Public Administration, Vol 72, pp. 527-549.

Shand, David and Paul Anand (1996), "Performance Auditing in the Public Sector: Approaches and Issues in OECD Member Countries", in Performance Auditing and the Modernisation of Government, PUMA, pp. 56-104.

Silaen, Parulian (2009),"Management Control Systems in Research and Development Organisations, Concept and Implementation: A Multiple Case Study in Indonesia", VDM Publishing House, Germany.

Silaen, Parulian and Robert Williams (2009), "Management control systems: a model for R\&D units", Accounting Research Journal, vol.22, no. 3, pp. 262274.

Smith, Charles, H., Roy A. Lanier, and Martin E. Taylor ((1972), "The Accounting Review", April, pp. 270-283). 
Wynn-Williams, K.L.H. (2005): "Performance Assessment and Benchmarking in the Public Sector. An Example from New Zealand", Benchmarking: An International Journal, Vol. 12, pp.482-492.

Zavelberg, Heinz Gunter, "Performance Auditing in Federal Republic of Germany", International Journal of Government Auditing, October, 1990, pp. 5-7, 16. 